\title{
Sea-Surface Dynamics Changes in the Subpolar North Atlantic Ocean (IODP Site U1314) during Late Pliocene Climate Transition Based on Calcareous Nannofossil Observation
}

\author{
Resti Samyati Jatiningrum¹, Tokiyuki Sato ${ }^{2}$ \\ ${ }^{1}$ Department of Geosciences, Geotechnology and Materials Engineering for Resources, Akita University, Akita, Japan \\ ${ }^{2}$ Faculty of International Resources Sciences, Akita University, Akita, Japan \\ Email: restisamyati@gmail.com, toki@gipc.akita-u.ac.jp
}

How to cite this paper: Jatiningrum, R.S. and Sato, T. (2017) Sea-Surface Dynamics Changes in the Subpolar North Atlantic Ocean (IODP Site U1314) during Late Pliocene Climate Transition Based on Calcareous Nannofossil Observation. Open Journal of Geology, 7, 1538-1551. https://doi.org/10.4236/ojg.2017.710103

Received: September 24, 2017

Accepted: October 24, 2017

Published: October 27, 2017

Copyright $\odot 2017$ by authors and Scientific Research Publishing Inc. This work is licensed under the Creative Commons Attribution International License (CC BY 4.0).

http://creativecommons.org/licenses/by/4.0/

\section{(c) (i) Open Access}

\begin{abstract}
Calcareous nannofossils were observed to reconstruct the surface water conditions during late Pliocene climate transition ( 2.55 to $2.88 \mathrm{Ma}$ ) from the southern Gardar Drift, in the subpolar North Atlantic IODP Site U1314 $\left(56^{\circ} 21.9^{\prime} 1 \mathrm{~N}, 27^{\circ} 53.3^{\prime} \mathrm{W}\right)$. A total of 24 species from 14 genera were identified by polarizing microscope observation. The coccolith assemblages are dominated by species belonging to genus Reticulofenestra with different (size-defined) morphotype. Hence, changes in paleoceanographic condition are shown by the size variation of Reticulofenstra specimens. Before $2.76 \mathrm{Ma}$, the studied interval is characterized by the presence of an abundant larger $R e$ ticulofenstra group. It indicates warm oligotrophic and stable surface waters. At $\sim 2.76 \mathrm{Ma}$ the abundance of large Reticulofenstra decreased abruptly and alternated with small Reticulofenstra, suggesting collapse of sea surface stability with strong mixing condition. This event coeval with the final closure of the Central American Seaway (CAS) and the onset of intensified North Hemisphere Glaciation (NHG). Subsequently, the size variation of Reticulofenestra specimens exhibits a sequential pattern that is somewhere consistent with the interglacial-glacial cycle. The pattern begins with a gradual increase in size upward during interglacial suggesting warm oligotrophic and stable condition, and ends with an abrupt decrease in coccolith size during glacial suggesting eutrophic or strong mixing condition and destabilized sea surface waters.
\end{abstract}

\section{Keywords}

Late Pliocene, Sea-Surface Waters Conditions, Calcareous Nannofossil, Subpolar North Atlantic 


\section{Introduction}

Millennial-scale climate variability during Pliocene has received considerable attention in the past years because during this period a warm and stable global climate was gradually alternating to a cooler climate characterized by glacial-interglacial cycles. Glacial amplitudes started to increase at $2.75 \mathrm{Ma}$, reflected by the first obliquity cycles with high $\delta^{18} \mathrm{O}$ or the beginning of the 41-kyr world, marking the substantial waxing and waning of the Northern Hemisphere ice sheets subsequently become characteristic of the Quaternary climate. This event appeared approximately coeval with the final closure of the Central American Seaway (CAS) and the associated change in thermohaline circulation [1] [2] [3] [4]. The stepwise closure of the CAS led to a drastic change in the global surface water circulation systems and global climates. The subpolar North Atlantic is considered one of the most climatically sensitive regions for its influence on reaction to global climate variation. Integrated Ocean Drilling Program (IODP) Site U1314 is located inside subpolar gyre in the southern Gardar Drift (Figure 1). The study area is strongly influenced by the North Atlantic Current (NAC), which originates from the Gulf Stream and able to record changes in the surface circulation of the subpolar gyre [5]. Moreover, the Gardar Drift had a relatively rapid accumulation of sediments and proven to contain high-resolution archives of variations in climatic and environmental conditions.

Calcareous nannoplanktons are influenced by surface water properties such as sunlight, salinity, temperature, turbidity and nutrient content within the photic zone [6]. Their biogeography and diversity are controlled by environmental changes in surface water. Thus, changes in abundance of some species of calcareous nannoplankton can be used to reconstruct palaeoceanographic changes on the sea-surface [6] [7] [8]. Various researchers have been investigated the dynamics of the past ocean condition in the subpolar North Atlantic and its relation to the timing of the closure CAS based on microfossils, deep-sea sediments, chemical components, and their association [9] [10] [11]. However, calcareous nannofossil studies during late Pliocene in this area have not been done yet. Besides, in the study site well-preserved foraminiferas are rarely found in the Pliocene sediments [12] [13], well-preserved calcareous nannofossils are found abundantly. Therefore, we focus on calcareous nannofossil assemblages to reconstruct the sea surface dynamic changes during late Pliocene climate transition between 2.87 and $2.55 \mathrm{Ma}$ and deliberation of the timing of tectonic events, notably the closure of Central CAS.

\section{Materials and Methods}

\subsection{Materials}

IODP Site U1314 is located in the southern Gardar Drift, in the subpolar North Atlantic at $56^{\circ} 21.9^{\prime} 1 \mathrm{~N}, 27^{\circ} 53.3^{\prime} \mathrm{W}$ in a water depth $2820 \mathrm{~m}$. Nannofossil and clay rich sediments which consists of late Pliocene calcareous nannofossil were collected from a completed splice section. The splice section was obtained down 


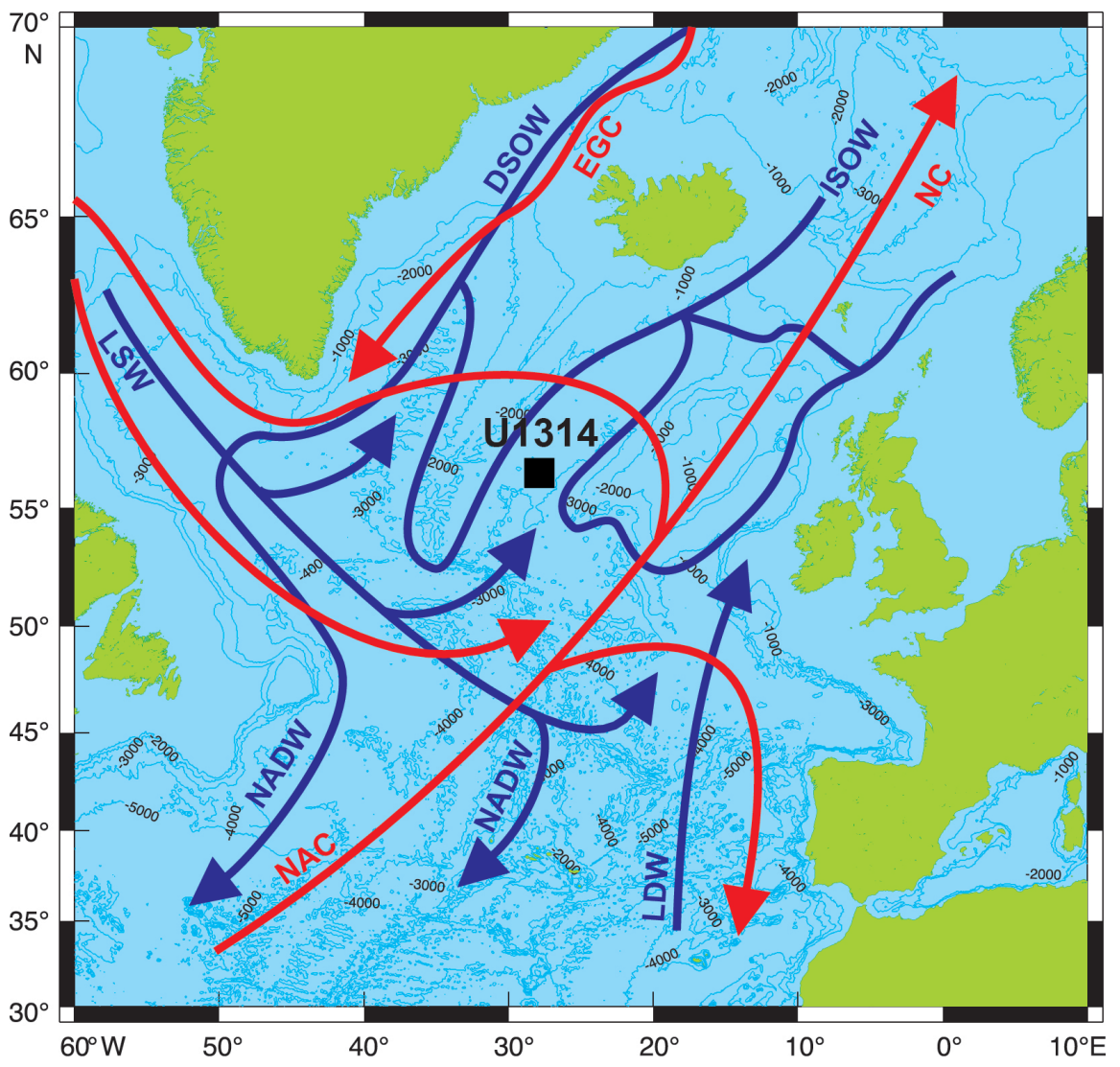

Figure 1. Location of IODP Site U1314 in the subpolar North Atlantic (black square). Red arrows represent North Atlantic surface circulation after Schmitz and McCartney [14]. Blue arrows represent deep ocean circulation after Dickson et al. [15]. EGC: East Greenland Current; NC: Norwegian Current; NAC: North Atlantic Current; DSOW: Denmark Strait Overflow water; ISOW: Iceland Scotland Overflow water; LSW: Labrador Sea water; NADW: North Atlantic Deep water; LDW: Lower Deep Water. The base map was provided by IODP.

to 281 mcd (meter composite depth) from the cores of three holes (Holes A, B, and $\mathrm{C}$ ) drilled with an advanced piston corer using non-magnetic core barrels [16]. The two deepest cores of Hole B were appended to the splice down to 299 mcd [11]. Hayashi et al. [13] constructed an orbital resolution age model for the period of $2.1-2.75 \mathrm{Ma}$ by tuning a hybrid environmental proxy record to the global-standard oxygen isotope curve [17]. Afterward, Sato et al. [11] modified the age model partly and extended the age model up to $2.9 \mathrm{Ma}$. They used magnetic susceptibility (MS) and natural gamma radiation (NGR) as tuning materials where the short-term variations (associated with iced-rafted debris) are eliminated.

\subsection{Nannofossil Observation and Analysis}

In this study, a total 131 samples were analyzed from 235.1 to $299.1 \mathrm{mcd}$ of the spliced section composed of Holes $\mathrm{A}$ and $\mathrm{B}$, which correspond to ages between 2.55 and $2.88 \mathrm{Ma}$ at an average resolution of $3 \mathrm{kyr}$. Smear slides were prepared 
following Bown and Young [18]. Calcareous nannofossils were examined under an Olympus BX53-P polarized light microscope with an oil-immersion objective lens at a magnification of $1000 \times$. Two hundred nannofossil specimens were identified and counted in straight transect across the micro slide to clarify the stratigraphic distribution of each species and its relative abundance. Additional observation were made along four to five other transects to investigate occurrences of other rare species. Nannofossils are moderate to well preserve and rare to very abundant throughout the studied sections. At the same time, the coccolith size of genera Reticulofenestra was measured to characterize the stratigraphic size distribution throughout the interval. In order to discuss the paleoceanographic condition in the subpolar North Atlantic we correlated the selected calcareous nannofossil assemblage with isotope oxygen stratigraphy [17], MS and NGR records [16].

\section{Result}

At least 24 species belonging to 14 genera were identified in late Pliocene sediments of IODP Site U1314 in the subpolar North Atlantic. A chart showing the distribution nannofossil abundances is given in Figure 2. One calcareous nannofossil datum is found within the samples interval, which is the last occurrence (LO) of Discoaster tamalis $(272.81 \mathrm{mcd})$. In this study, the LO of D. tamalis dates to an age $2.76 \mathrm{Ma}$. The estimated age is derived from age model developed by Hayashi et al. [13] afterward modified by Sato et al. [11] by astronomically tuning in physical and magnetic properties (magnetic susceptibility and natural gamma radiation) to the LR04 $\delta^{8} \mathrm{O}$ records [17]. Based on the nannofossil event found at Site U1314, the studied interval is belonging to Zone NN16 [19]. However, referring to Okada and Bukry [20] the studied interval is included within

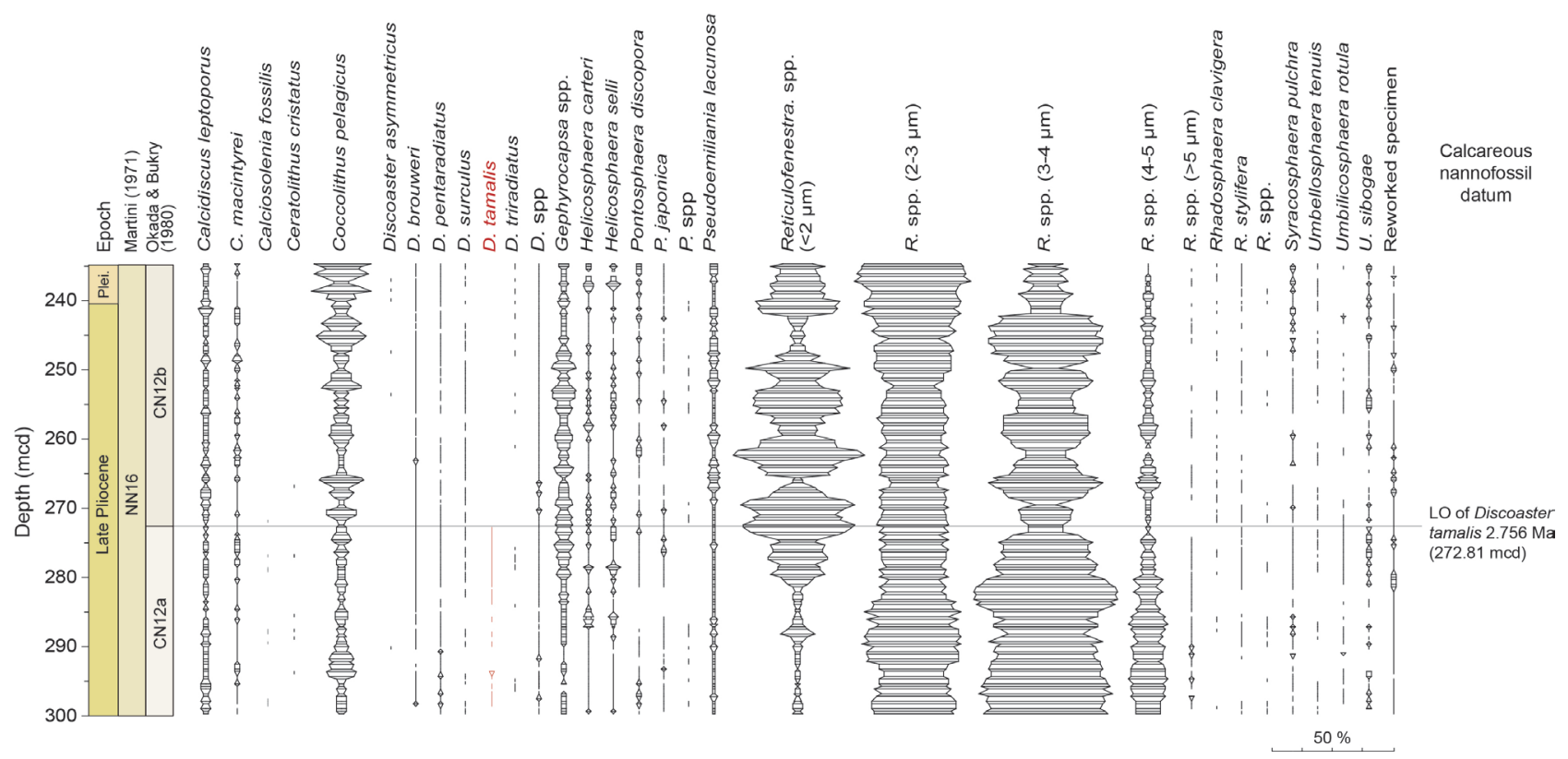

Figure 2. Stratigraphic distribution of calcareous nannofossils in IODP Site U1314. 
two Subzones, which are Subzones CN12b and CN12a as defined by the LO of $D$. tamalis. Below the LO of D. tamalis or Subzone CN12a, the sequence is characterized by the abundance occurrence of larger Reticulofenestra spp. ( $>3 \mu \mathrm{m})$. In Subzone CN12b, the relative abundance of Reticulofenestra spp. $(>4 \mu \mathrm{m})$ is decreasing, whereas the relative abundance of small Reticulofenestra spp. $(<2$ $\mu \mathrm{m})$ and Coccolithus pelagicus are increasing.

The high presence of species belonging to the genus Reticulofenestra characterize the calcareous nannofossil assemblage, which comprise about $85 \%$ of the total coccolith assemblage for most of the sampling interval. The Reticulofenestra specimens ranging between $3-4 \mu \mathrm{m}$ is the most abundant group and has relatively higher abundance (34\% - 59\%) in the older part of the studied interval. In contrast, smaller Reticulofenestra specimens $(<2 \mu \mathrm{m})$ remain low and make up $1 \%-24 \%$ of the total coccolith assemblage. The larger species of Reticulofenestra $(>4 \mu \mathrm{m})$ were found throughout the section and they were most abundant before $\sim 280 \mathrm{mcd}$. The relative abundance of Reticulofenestra group of $2-3 \mu \mathrm{m}$ is ranging between $18 \%-48 \%$ in all samples. The drastic change in Reticulofenestra assemblage was first observed at $\sim 280 \mathrm{mcd}$. At this point the dominant abundance of relatively larger Reticulofenestra specimens alternate with smaller Reticulofenestra specimens (between 2\% - 53\%). The species of Coccolithus pelagicus is forming $1 \%-25 \%$ of the total coccolith assemblages. Other species recorded consistently in the samples are Calcidiscus leptoporus, Calcidiscus macintyeri, small Gephyrocapsa, Helicosphaera carteri, Helicosphaera selli, and Pseudoemiliania lacunosa. Together they form less than $1 \%-17 \%$ of the total coccolith assemblages. Calciosolenia fossilis, Ceratolithus cristatus, Discoaster spp., Pontosphaera spp., Rhabdosphaera spp., Umbellosphaera spp., and Umbilicosphaera spp. are present within the assemblages in minor percentages $(<3 \%)$ and scattered occurrence. Reworked specimens are present throughout the sample interval but are not a major component of the sediments, and only a few specimens of Miocene and Paleogene taxa are observed. We discuss below only the species and groups that are most abundant or that are significant from a palaeoecological point.

\section{Discussions}

\subsection{Coccolith Size Variation of Reticulofenestra}

Changes in the coccolith size of Reticulofenestra are commonly used as a paleoceanographic indicator and have been examined through Cenozoic [21] [22] [23] [24] [25]. Sato and Chiyonobu [26] studied calcareous nannofossil assemblages in the Ocean Drilling Program (ODP) holes 807A and 807C in the western equatorial Pacific Ocean, and Hole 731A in the Indian Ocean. They discussed a vertical distribution of calcareous nannofossil during well-developed stratification and strong mixing conditions (Figure 3). According to them, during oligotrophic and well-developed stratification condition is characterized by decrease in coccolith production and small Reticulofenestra along with increase in abundance of lower photic zone taxa. In contrast, increase in coccolith production 
(A) Oligotrophic condition

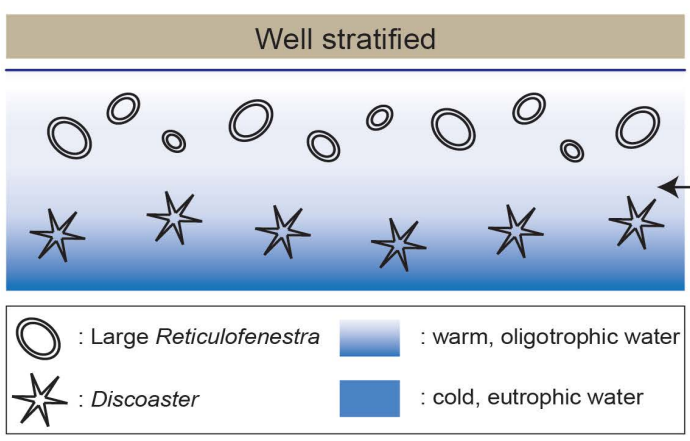

(B) Eutrophic condition

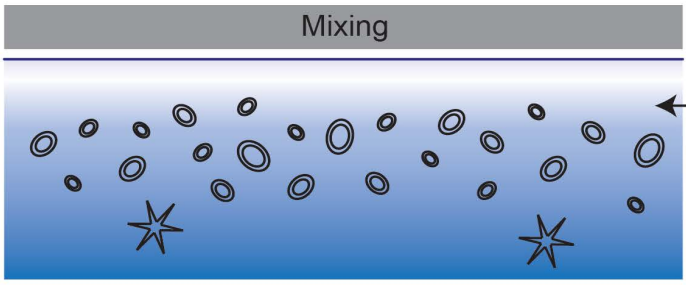

Sea Surface

Top of Thermocline and Nutricline

Base of Photic Zone $(200 \mathrm{~m})$

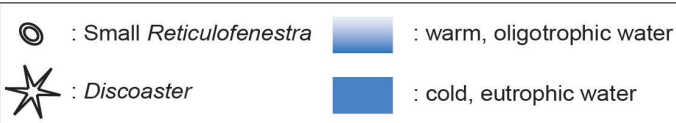

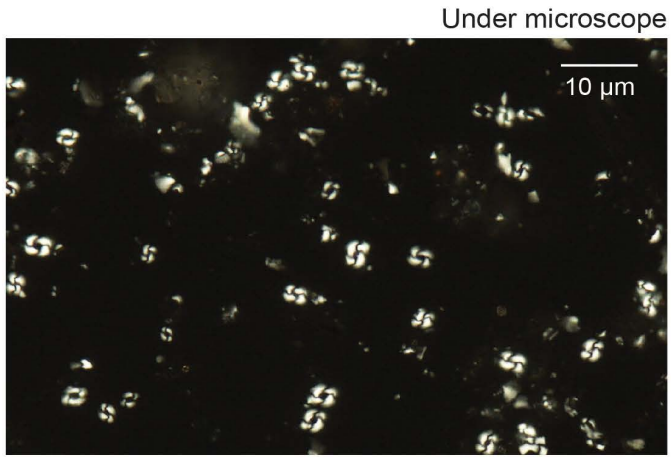

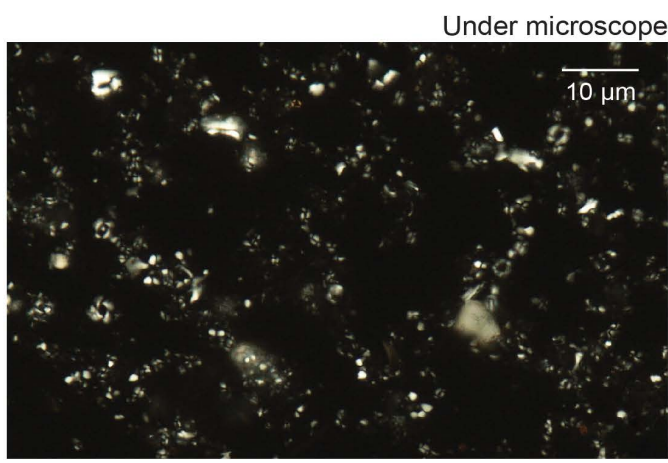

Figure 3. Vertical distribution of Miocene to Pliocene calcareous nannofossil assemblages under (A) oligotrophic condition and (B) eutrophic condition (modified after Sato and Chiyonobu [26]) together with photomicrographs. Photomicrographs of calcareous nannofossils were obtained from (A) B30H-4W-C and (B) B27H-6A-13.

and small Reticulofenstra and decrease in abundance of lower photic zone taxa characterize eutrophic or strong mixing condition. In addition, Farida et al. [27] suggested that changes in coccolith size of Reticulofenestra reflect the progressive collapse of sea surface stability during the late Neogene.

Changes in coccolith size of Reticulofenestra during late Pliocene were visible in IODP Site U1314 (Figure 4). An abrupt decrease in coccolith size of Reticulofenestra was recorded first in the MIS G8 and MIS G7 or just below the LO of $D$. tamalis which dates to an age $\sim 2.76 \mathrm{Ma}$. The datum event is situated within late Gauss Normal Chron or just below Marine Isotope Stage (MIS) G7 (Figure 5). This event corresponds to similar rapid change identified in coccolith size of Reticulofenestra in the North Atlantic Ocean by Kameo and Takayama [23]. Sato and Kameo [28] discussed a possible correlation between Datum A and the LO of $D$. tamalis. Datum A is an event conceived with a nannofloral change from abundant Reticulofenestra spp. (small) and Dictyococcites spp. (small) to a barren interval or to Coccolithus pelagicus dominated assemblages. This nannofloral change indicates paleoclimate changes from warmer to cooler environment, linked to the increase of ice sheets in the northern hemisphere [28]. Thereby, the abrupt decrease that observed in our site is might be related to the late Pliocene heavy glaciations in high-latitude regions. Subsequent to $2.76 \mathrm{Ma}$, the size variations of Reticulofenestra exhibits sequential pattern. The pattern begins with gradual increases in size upward and ends with an abrupt decrease in 


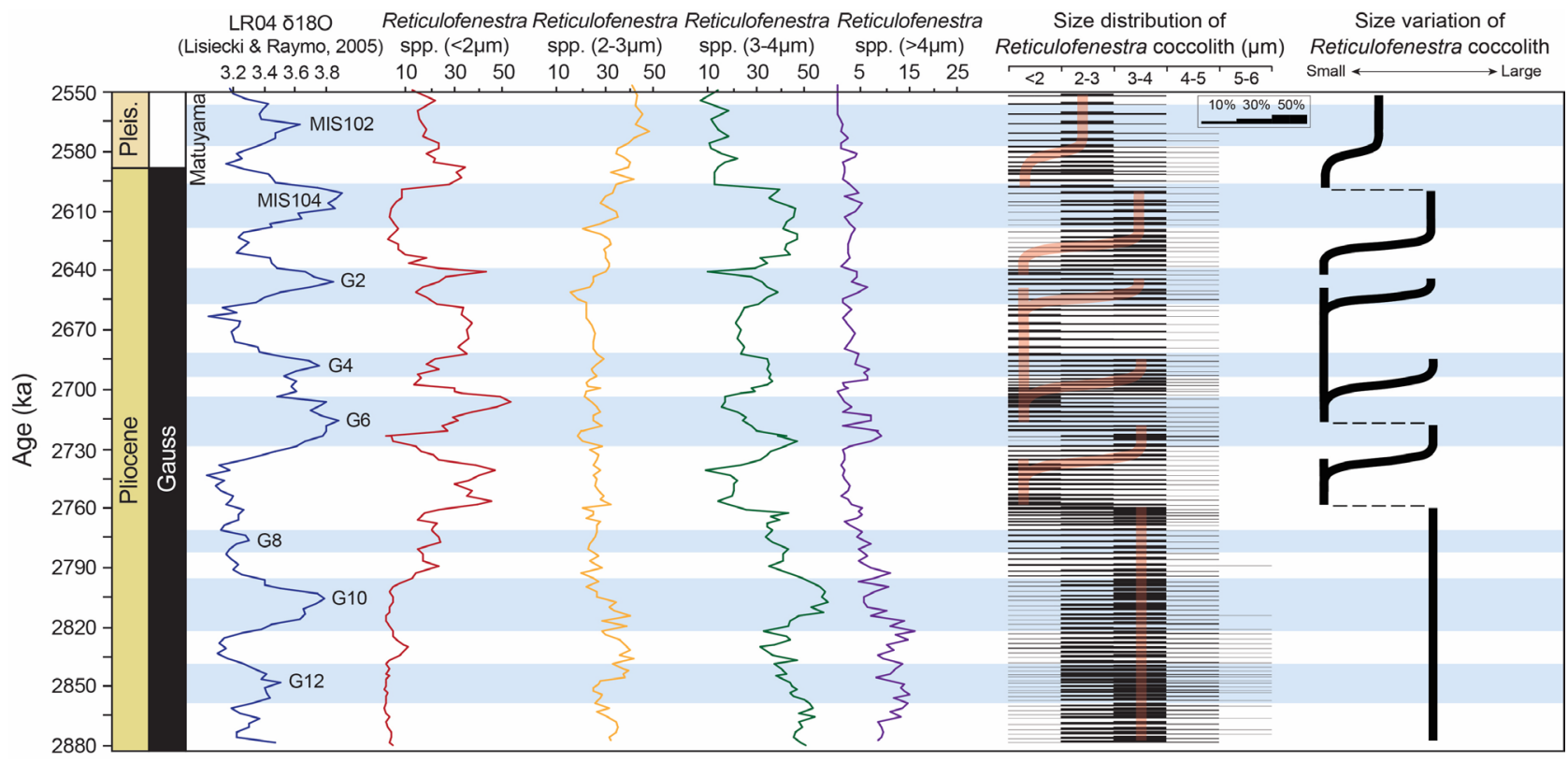

Figure 4. Comparison between different morphotype (size-defined) Reticulofenestra spp. percentage (\%), isotope oxygen stratigraphy [17] and coccolith size distribution of Reticulofenestra. Blue bands represent the glacial periods.

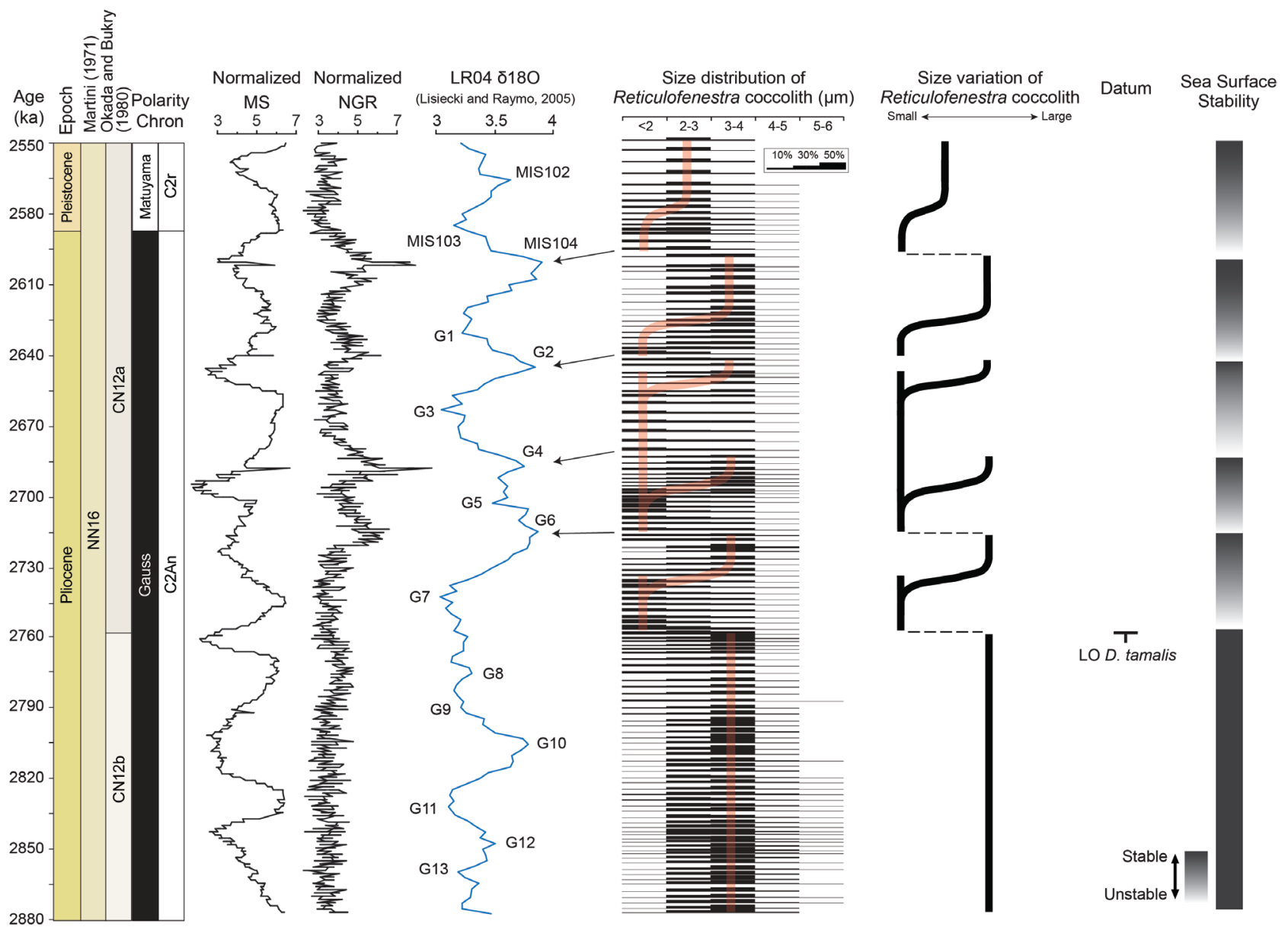

Figure 5. Size distribution and size variation of Reticulofenestra coccolith compare with isotope oxygen stratigraphy [17], normalized MS, and normalized NGR [16] and its relation to the sea surface stability. 
coccolith size. This transition is somewhere consistent with the interglacial-glacial cycle that can be seen in the benthic foraminifera oxygen isotope data [17], when the amplitude of the $41 \mathrm{ka}$ component start to increase (Figure 4). Hence, our results confirm that the changes in coccolith size of Reticulofenestra were affected by the variability of sea surface condition.

Detail looks at relative Reticulofenestra specimens $(<2 \mu \mathrm{m}$ and $3-4 \mu \mathrm{m})$ abundance recorded at Site U1314 reveals that the Reticulofenestra specimens closely follow the $\delta^{18} \mathrm{O}$ records (Figure 4). It is likely reflecting a strong climate control (presumably ice volume signal). Reticulofenestra spp. 3 - $4 \mu \mathrm{m}$ in size shows a negative correlation with the LR04 $\delta^{18} \mathrm{O}$ stacks [17], on the other hand, the $<2 \mu \mathrm{m}$ in size of Reticulofenestra spp. shows a positive correlation. Coccolith size can be influenced by various factors, such as resource availability and/or climatic change on shorter time-scales to evolutionary process on longer timescales [29]. The correspondence between $<2 \mu \mathrm{m}$ and $3-4 \mu \mathrm{m}$ coccolith size of Reticulofenestra specimens and their relative abundance demonstrates that the possibility of the major driving force of the observed size variability is regional coccolithophores ecology. Those two morphotypes might be having a different preference of ecology or different species. Further detail in taxonomic studies is needed to be able to explain better about the driving force of the size variability. The smaller Reticulofenestra specimens $(<2 \mu \mathrm{m})$ are usually found in higher abundance during glacial periods. Our results seem coherent with previous coccolith studies by Sato and Chiyonobu [26]. They observed increases in coccolith production and the relative abundance of small Reticulofenestra during glacial periods that might be led from enhanced nutrient transport to the sea surface from the lower photic, triggering eutrophic condition. At Site U1314 the higher nutrient input might be due to increasing of ice sheets that drove to higher velocity of sea surface circulation, caused a collapse of sea surface waters and/or IRD transport and deposition as showed with a higher value of NGR during the glacial periods (Figure 5). Raven [30] describe smaller unicellular phytoplankton cells have higher nutrient-uptake and growth rates follow general allometric rule. Consequently, the abrupt decrease of the maximum size of Reticulofenestra coccolith to smaller size coccolith during glacial periods can be interpreted as its adaptation to unfavorable conditions, relative to larger specimens, in exploiting limited resources, as well as a (re)occupation of probable ecological niches. Some delays are observed in the peak of small Reticulofenestra $(<2 \mu \mathrm{m}$, Figure 3$)$ abundance compared with the $\delta^{18} \mathrm{O}$ record of Lisiecki and Raymo [17]. The offset of the delays is mainly about $10 \mathrm{kyr}$, relatively. The delays might be representing an adaptation of some taxa, which benefited from oligotrophic environments before the ecological collapse occurred.

\subsection{Sea Surface Dynamics Changes during Late Pliocene Climatic Crash in the Subpolar North Atlantic}

Observed coccolith size distribution of Reticulofenestra in the IODP Site U1314 grants us to assess the paleoceanography of the study site. Prior to $2.76 \mathrm{Ma}$, the 
sea surface condition in the study site remains stable in oligotrophic condition as suggested by an abundance of medium to large Reticulofenstra. This period is likely the extension of Mid-Pliocene warm influence, suggesting a significant transfer of heat northwards from the low latitudes to the high latitudes [31] [32] as a result of the closure of CAS [4] [33] [34]. The natural gamma radiation (NGR) values are very low or almost constant (Figure 5), indicating no detrital input to the site area. However, magnetic susceptibility (MS) shows fluctuating values and exhibits global ice volume changes reflected in the $\delta^{18} \mathrm{O}$ stack [17] (Figure 5). The main source of sediment in the Gardar Drift is pelagic sediment that has been eroded and redeposited by the southward flowing Iceland Scotland Overflow Water (ISOW) and Northeast Atlantic Deep Water (NEADW) [35]. Sato et al. [11] observed sediments transported by ISOW represent the intensity of NADW formed at the Nordic Seas and concluded little or no deep-water formation had occurred at the Nordic Seas before MIS G5. Besides, McKay et al. [36] suggested an increased sea ice extent in Antarctic or the Southern Ocean resulted in increased northward influx of Antarctic Bottom Water (AABW) formation and intensified Lower Deep Water (LDW). Therefore, it indicates that the sediments deposition as reflected in the MS records had mainly been controlled by cyclic developments of the Antarctic ice sheets that drove sea level changes before $\sim 2.76 \mathrm{Ma}$.

Subsequent to stable condition during Mid-Pliocene warm, ice sheets around the Nordic Seas and North Atlantic develop drastically at 2.75 Ma [37] [38] [39]. In our study, calcareous nannofossil assemblage which is characterized by coccolith size variations of Reticulofenestra show an abrupt reduction in the maximum size of coccolith at around $2.76 \mathrm{Ma}$. It corresponds with the increased relative abundance of small Reticulofenstra, suggesting a collapse of sea surface stability and strong mixing condition. The MS and NGR values are in agreement with the calcareous nannofossil data. It shows a short-term decrease and increase near the LO of $D$. tamalis (Figure 5), indicates an episodic input of nonmagnetic minerals (possibly IRD) [13]. The timing of this event appears to be correlated with the closure of CAS and the onset of heavy glaciation in the North Hemisphere. The final closure of CAS is considered to take place at around 2.7 $\mathrm{Ma}$ and the event led to establishing of the Quaternary style climate. Kameo and Sato [40] elucidated the final closure of CAS occurred at $2.74 \mathrm{Ma}$ based on the end of similarities between calcareous nannofossil assemblages in the Caribbean and the eastern equatorial Pacific regions. Moreover, paleobiogeography of Coccolithus pelagicus studied by Sato et al. [9] reveals that the drastic changes in paleobiogeography of C. pelagicus are related to the final closure of CAS and onset of heavy glaciation in the Arctic Sea and North Pacific Ocean at 2.74 Ma. In addition, Bartoli et al. [4] noted that between 2.95 and $2.83 \mathrm{Ma}$, just before the onset of the North Hemisphere Glaciation, SSTs rose by $2^{\circ} \mathrm{C}-3^{\circ} \mathrm{C}$ and persisted until at least $2.5 \mathrm{Ma}$. Thus, a combination of different paleoceanographic proxies may provide clear data and the effect of the final closure of CAS on global circu- 
lation and/or climate changes can be described in more detail.

After $\sim 2.76 \mathrm{Ma}$, the sequential pattern of size variations of Reticulofenestra is somewhere consistent with the interglacial-glacial cycle (Figure 5), where increasing in $\delta^{8} \mathrm{O}$ values or known as glacial periods concurrently with the occurrence of higher abundance of smaller Reticulofenestra. The increased smaller Reticulofenestra during MIS G6, MIS G4, MIS G2, MIS 104, and MIS 102 suggest a collapse of sea surface stability with mixing condition and high productivity. During this periods ice sheets covered the higher latitude area and the Arctic front (AF) is known to have migrated southward, bringing much cooler waters and potentially also sea ice south of $60^{\circ} \mathrm{N}$ [41] [42] [10]. The AF is the boundary between the Arctic water and the warm and high salinity Atlantic water. It is characterized by high eddy activity that promotes surface water productivity [10]. The cause of a collapse of sea surface water and mixing condition in the study area was probably when the ice sheets increased in the northern hemisphere that led to higher velocity of sea surface circulation, the southward migration of the subpolar front or both.

\section{Conclusion}

Calcareous nannofossil assemblage study in the IODP Site U1314 with a wellconstrained age for the last 2.55 to $2.88 \mathrm{Ma}$ reveals changes in surface ocean waters and its relation to the climatic changes during late Pliocene climate crash in the subpolar North Atlantic. Also, our result confirms that the coccolith size variations of Reticulofenestra specimens are affected by the variability of sea surface condition. Before $\sim 2.76 \mathrm{Ma}$, the surface ocean condition was very stable with a warm and oligotrophic condition, as characterized by the dominance of medium and large Reticulofenestra specimens with low detrital input to the site area (low NGR values). This condition suggests incomplete final closure of Central American Seaway (CAS) and the extension of Mid-Pliocene warm influence before $\sim 2.76 \mathrm{Ma}$. At around $2.76 \mathrm{Ma}$ the studied site marked by the collapse of sea surface stability with strong mixing condition. It is delineated by an abrupt decrease of maximum coccolith of Reticulofenestra, reflects the intensification of Northern Hemisphere Glaciation (NHG) and correlates with the final closure of CAS. Afterward, in the late Pliocene epoch, when Quaternary style climate established, larger Reticulofenestra specimens that indicate warm oligotrophic and stable ocean condition characterize the interglacial periods. The periods ended with shifting dominance larger Reticulofenestra specimens to smaller size during glacial periods, that denotes unstable of sea surface and mixing condition. The mixing condition or higher nutrient input in IODP Site U1314 might due to increase of ices heets that lead to higher velocity of sea surface circulation causes a collapse of sea surface waters, IRD transport and deposition that are triggering eutrophic conditions, the southward migration of the subpolar front, or combination of all factors. Some delays of small Reticulofenestra peak observed in about $10 \mathrm{kyr}$, relatively, as characterized by unstable sea surface and mixing condition. It indi- 
cates smaller specimens of Reticulofenestra specimens are likely more adaptable to unfavorable conditions, yet the delays suggest an adaptation of some taxa, which benefited from oligotrophic environments before the ecological collapse occurred. Further work the combination of different paleoceanographic proxies are needed to elucidate the paleoceanography condition in the subpolar North Atlantic during late Pliocene epoch and the influence of the final closure of CAS on global circulation and/or climate changes in more detail.

\section{Acknowledgements}

Sample for this study were provided by Integrated Ocean Drilling Program. This work was supported by the Ministry of Education, Culture, Sports, Science and Technology (MEXT) Monbukagakusho.

\section{References}

[1] Maier-Reimer, E., Mikolajewicz, U. and Crowley, T. (1990) Ocean General Circulation Model Sensitivity Experiment with an Open Central American Isthmus. Paleoceanography, 5, 349-366. https://doi.org/10.1029/PA005i003p00349

[2] Raymo, M.E., Grant, B., Horowitz, M. and Rau, G.H. (1996) Mid-Pliocene Warmth: Stronger Greenhouse and Stronger Conveyor, Mar. Micropaleontology, 27, 313-326. https://doi.org/10.1016/0377-8398(95)00048-8

[3] Ravelo, A.C. and Andreasen, D.H. (2000) Enhanced Circulation during a Warm Period. Geophysical Research Letters, 27, 1001-1004.

https://doi.org/10.1029/1999GL007000

[4] Bartoli, G., Sarnthein, M., Weinelt, M., Erlenkeuser, H., Garbe-Schönberg, D. and Lea. D.W. (2005) Final Closure of Panama and the Onset of Northern Hemisphere Glaciation. Earth and Planetary Science Letters, 237, 33-44. https://doi.org/10.1016/j.epsl.2005.06.020

[5] Alonso-Garcia, M., Sierro, F.J., Kucera, M., Flores, J.A., Cacho, I. and Andersen, N. (2011) Ocean Circulation, Ice Sheet Growth and Interhemispheric Coupling of Millennial Climate Variability during the Mid-Pleistocene (ca 800-400ka). Quaternary Science Reviews, 30, 3234-3247.

https://doi.org/10.1016/j.quascirev.2011.08.005

[6] McIntyre, A. and Bé, A.H. (1967) Modern Coccolithophoridae of the Atlantic Ocean-I. Placoliths and Cyrtoliths. Deep Sea Research, 14, 561-597. https://doi.org/10.1016/0011-7471(67)90065-4

[7] Giraudeau, J. (1992) Distribution of Recent Nannofossil Beneath the Benguela System: Southwest African Continental Margin. Marine Geology, 108, 219-237. https://doi.org/10.1016/0025-3227(92)90174-G

[8] Takahashi, K. and Okada, H. (2000) The Paleoceanography for the Last 30,000 Years in the Southeastern Equatorial Indian Ocean by Means of Calcareous Nannofossils. Marine Micropaleontology, 40, 83-103. https://doi.org/10.1016/S0377-8398(00)00033-5

[9] Sato, T., Yuguchi, S., Takayama, T. and Kameo, K. (2004) Drastic Change in the Geographical Distribution of the Cold-Water Nannofossil Coccolithuspelagicus (Wallich) Schiller at 2.74 Ma in the Lzate Pliocene, with Special Reference to Glaciation in the Arctic Ocean. Marine Micropaleontology, 52, 181-193.

https://doi.org/10.1016/j.marmicro.2004.05.003 
[10] Naafs, B.D.A., Stein, R., Hefter, J., Khélifi, N., de Schepper, S. and Haug, G.H. (2010) Late Pliocene Changes in the North Atlantic Current. Earth and Planetary Science Letters, 298, 434-442. https://doi.org/10.1016/j.epsl.2010.08.023

[11] Sato, M., Makio, M., Hayashi, T. and Ohno, M. (2015) Abrupt Intensification of North Atlantic Deep Water Formation at the Nordic Seas during the Late Pliocene Climate Transition. Geophysical Research Letters, 42, 4949-4955. https://doi.org/10.1002/2015GL063307

[12] Channell, J.E.T., Mazaud, A., Sullivan, P., Turner, S. and Raymo, M.E. (2002) Geomagnetic Excursions and Paleointensities in the Matuyama Chron at Ocean Drilling Program Sites 983 and 984 (Iceland Basin). Journal of Geophysical Research, 107, 2114. https://doi.org/10.1029/2001JB000491

[13] Hayashi, T., Ohno, M., Acton, G., Guyodo, Y., Evans, H.F., Kanamatsu, T., Komatsu, F. and Murakami, F. (2010) Millennial-Scale Iceberg Surges after Intensification of Northern Hemisphere Glaciation. Geochemistry, Geophysics, Geosystems, 11, Q09Z20. https://doi.org/10.1029/2010GC003132

[14] Schmitz, W.J. and McCartney, M. (1993) On the North Atlantic Circulation. Reviews in Geophysics, 31, 29-49. https://doi.org/10.1029/92RG02583

[15] Dickson, R.R., Gmitrowicz, E.M. and Watson, A.J. (1990) Deep-Water Renewal in the Northern North Atlantic. Nature, 344, 848-850.

https://doi.org/10.1038/344848a0

[16] Expedition 306 Scientists (2006) Site U1314. Proc. Integr. Ocean Drill. Program, 306, 1-95.

[17] Lisiecki, L.E. and Raymo, M.E. (2005) A Pliocene-Pleistocene Stack of 57 Globally Distributed Benthic $\delta^{18} \mathrm{O}$ Records. Paleoceanography, 20, PA1003. https://doi.org/10.1029/2004PA001071

[18] Bown, P.R. and Young, J.R. (1998) Techniques. In: Bown, P.R., Ed., Calcareous Nannofossil Biostratigraphy, Chapman and Hall (Kluwer Academic Publishers), Dordrecht, 16-28. https://doi.org/10.1007/978-94-011-4902-0 2

[19] Martini, E. (1971) Standard Tertiary and Quaternary Calcareous Nannoplankton Zonation. In: Farinacci, A., Ed., Proceedings of the Second Planktonic Conference, Tecnoscienza, Roma, 739-785.

[20] Okada, H. and Bukry, D. (1980) Supplementary Modification and Introduction of Code Numbers to the Low-Latitude Coccolithbiostratigraphic Zonation (Bukry 1973, 1975). Marine Micropaleontology, 5, 321-325.

[21] Young, J.R. (1990) Size Variation of Neogene Reticulofenestra coccoliths from Indian Ocean DSDP Cores. Journal of Micropalaeontology, 9, 71-86. https://doi.org/10.1144/jm.9.1.71

[22] Gartner, S. (1992) Miocene Nannofossil Chronology in the North Atlantic, DSDP Site 608. Marine Micropaleontology, 18, Article ID: 307331.

[23] Kameo, K. and Takayama, T. (1999) Biostratigraphic Significance of Sequential Size Variations of the Calcareous Nannofossil Genus Reticulofenestra in the Upper Pliocene of the North Atlantic. Marine Micropaleontology, 37, 41-52.

[24] Kameo, K., Shindo, R. and Takayama, T. (2010) Calcareous Nannofossil Biostratigraphy and Geologic Age of the Kiyosumi Formation of the Awa Group, Boso Peninsula, Central Japan: Age Determination Based on Size Variations of Reticulofenestra Specimens (in Japanese with English Abstract). The Journal of the Geological Society of Japan, 116, 563-574. https://doi.org/10.5575/geosoc.116.563

[25] Imai, R., Farida, M., Sato, T. and Iryu, Y. (2015) Evidence for Eutrophication in the 
Northwestern Pacific and Eastern Indian Oceans during the Miocene to Pleistocene Based on the Nannofossil Accumulation Rate, Discoaster Abundance, and Coccolith Size Distribution of Reticulofenestra. Mar. Micropaleontology, 116, 15-27.

[26] Sato, T. and Chiyonobu, S. (2009) Cenozoic Paleoceanography Indicated by Size Change of Calcareous Nannofossil and Discoaster Number (in Japanese with English Abstract). Fossils, 86, 12-19.

[27] Farida, M., Imai, R. and Sato, T. (2012) Miocene to Pliocene Paleoceanography of the Western Equatorial Pacific Ocean Based on Calcareous Nannofossils, ODP Hole 805B. Open Journal of Geology, 2, 72-79. https://doi.org/10.4236/ojg.2012.22008

[28] Sato, T. and Kameo, K. (1996) Pliocene to Quaternary Calcareous Nannofossil Biostratigraphy of the Arctic Ocean, with Reference to Late Pliocene glaciation. Proceedings of the Ocean Drilling Program. Scientific Results, 151, 39-59.

[29] Henderiks, J. and Pagani, M. (2008) Coccolithophore Cell Size and the Paleogene Decline in Atmospheric $\mathrm{CO}_{2}$. Earth and Planetary Science Letters, 269, 576-584.

[30] Raven, J.A. (1998) The Twelfth Tansley Lecture. Small Is Beautiful: The Picophytoplankton. Functional Ecology, 12, 503-513. https://doi.org/10.1046/j.1365-2435.1998.00233.x

[31] Bartoli, G., Sarnthein, M. and Weinelt, M. (2006) Late Pliocene Millennial-Scale Climate Variability in the Northern North Atlantic prior to and after the Onset of Northern Hemisphere glaciation. Paleoceanography, 21, 1-15. https://doi.org/10.1029/2005PA001185

[32] Dowsett, H.J., Chandler, M.A. and Robinson, M.M. (2009) Surface Temperatures of the Mid-Pliocene North Atlantic Ocean: Implications for Future Climate. Philosophical Transactions of the Royal Society A, 367, 69-84. https://doi.org/10.1098/rsta.2008.0213

[33] Lunt, D.J., Valdes, P.J., Haywood, A.M. and Rutt, I. (2007) Closure of the Panama Seaway during the Pliocene: Implications for Climate and Northern Hemisphere glaciation. Climate Dynamics, 30, 1-18. https://doi.org/10.1007/s00382-007-0265-6

[34] Sarnthein, M., Bartoli, G., Prange, M., Schmittner, A., Schneider, B., Weinelt, M., Andersen, N. and Garbe-Schönberg, D. (2009) Mid-Pliocene Shifts in Ocean Overturning Circulation and the Onset of Quaternary-Style Climates. Climate of the Past, 5, 269-283. https://doi.org/10.5194/cp-5-269-2009

[35] Grützner, J. and Higgins, S.M. (2010) Threshold Behavior of Millennial Scale Variability in Deep Water Hydrography Inferred from a 1.1 Ma Long Record of Sediment Provenance at the Southern Gardar Drift. Paleoceanography, 25, PA4204. https://doi.org/10.1029/2009PA001873

[36] McKay, R., Naish T., Carter, L., Riesselman, C., Dunbar, R., Sjunneskog, C., Winter, D., Sangiorgi, F., Warren, C., Pagani, M., Schouten, S., Willmott, V, Levy, R., DeConto, R. and Powell, R.D. (2012) Antarctic and Southern Ocean Influences on Late Pliocene Global Cooling. PNAS, 109, 6423-6428. https://doi.org/10.1073/pnas.1112248109

[37] Keigwin, L.D. (1982) Neogene Planktonic Foraminifers from Deep-Sea Drilling Project Sites 502 and 503. Initial Reports of the Deep Sea Drilling Project, 68, 269-288. https://doi.org/10.2973/dsdp.proc.68.105.1982

[38] Jansen, E., Bleil, U., Henrich, R., Kringstad, L. and Slettemark, B. (1988) Paleoenvironmental Changes in the Norwegian Sea and the Northeast Atlantic during the Last 2.8 m.y.: Deep Sea Drilling Project/Ocean Drilling Program Sites 610, 642, 643 and 644. Paleoceanography, 3, 563-581.

https://doi.org/10.1029/PA003i005p00563 
[39] Kleiven, H.F., Jansen, E., Fronval, T. and Smith, T.M. (2002) Intensification of Northern Hemisphere Glaciations in the Circum Atlantic Region (3.5-2.4 Ma) -Ice-Rafted Detritus Evidence. Palaeogeography, Palaeoclimatology, Palaeoecology, 184, 213-223.

[40] Kameo, K. and Sato, T. (2000) Biogeography of Neogene Calcareous Nannofossils in the Caribbean and the Eastern Equatorial Pacific-Floral Response to the Emergence of the Isthmus of Panama. Marine Micropaleontology, 39, 201-218.

[41] Ruddiman, W.F. (1977) Late Quaternary Deposition of Ice-Rafted Sand in the Subpolar North Atlantic (Lat $40^{\circ}$ to $65^{\circ} \mathrm{N}$ ). Geological Society of America Bulletin, 88, 1813-1827. https://doi.org/10.1130/0016-7606(1977)88<1813:LQDOIS >2.0.CO;2

[42] Wright, A.K. and Flower, B.P. (2002) Surface and Deep Ocean Circulation in the Subpolar North Atlantic during the Mid-Pleistocene Revolution. Paleoceanography, 17, 1068. https://doi.org/10.1029/2002PA000782 